\title{
Benefits and Challenges of Applying Computational Thinking in Education
}

\author{
Noor Desiro Saidin, Fariza Khalid, Rohanilah Martin, Yogeswary Kuppusamy, and Nalini A/P \\ Munusamy
}

\begin{abstract}
Computational thinking (CT) is one of the skills or processes needed in computer science. However, these skills can also be integrated into any field in education. The objective of this literature review is to study the benefits and challenges of computational thinking (CT) in education. This literature review is analyses 55 references obtained from various sources, based on predefined keywords. The references were then analysed using NVivo software to code them according to several main points. Based on the literature review, there are many benefits of computational thinking in education, including increasing critical and analytical thinking among students, cultivating CT skills in STEM education among students, improving pedagogy and curriculum, and fostering CT skills through game-based learning (GBL). However, there are some challenges facing the implementation of computational thinking in the field of education. These include teachers' understanding of computational CT, lack of confidence, lack of the skills required to implement CT, and students' acceptance of CT. In order to overcome these challenges, there are two important aspects to consider: ensuring teachers' level of knowledge and level of readiness about CT is high. It is hoped that this literature review will be able to provide educators with an understanding of the extent to which CT is able to shape education to be more creative and meaningful.
\end{abstract}

Index Terms-Computational thinking, benefits, education, CT.

\section{INTRODUCTION}

Teaching and learning are becoming increasingly challenging in line with the development of education in the twenty-first century. In the era of information and modern technology, education needs to be aligned with current needs. Thus, various terms have been introduced into the world of education. One of them is Computational Thinking (CT).

$\mathrm{CT}$ is a fundamental skill that needs to be mastered from early education to higher education in order to effectively solve problems in the world of digital technology. CT also provides an opportunity for individuals to develop their knowledge and skills to succeed in life [1].

The term CT was first introduced by Seymour Papert in 1980, in his book entitled Mindstorms: Children, Computers, Powerful Ideas and An Exploration in the Space of Mathematics Educations [2]. [3] defines CT as an approach

Manuscript received September 23, 2020; revised January 23, 2021. This work was conducted under GG-2019-068 grant.

The authors are with the Faculty of Education Universiti Kebangsaan, Malaysia (e-mail: dessyro90@gmail.com, fariza.khalid@ukm.edu.my, ielawaniela@gmail.com, mnalina1977@gmail.com). to problem solving, designing systems, understanding human behaviour, and illustrating basic computer science concepts. $\mathrm{CT}$ is then redefined as a thought process used to formulate a problem and to find a solution that can be translated into a form that can be effectively implemented by the information-processing agent [4], [5]. Using CT skills, learners can also solve cognitive problems using a variety of methods [6]. It also involves the preparation and analysis of data, finding solutions by using algorithms and solving problems [7].

CT is well known as a tool for problem-solving process that requires dividing problems into smaller components, extracting important and relevant ideas, and recognizing patterns to enable proper solution planning to avoid duplication and less-relevant actions to improve the effectiveness of the problem-solving process [8]. Using CT, learners can also build and devise solutions to a problem and to present the right solution [9]. In this way, it enables individuals to solve complex problems more effectively [3] and therefore, is important to be applied by students to improve the quality of their learning [10], [11].

There are several strategies for solving problems in CT approach that includes: decomposition, pattern recognition, generalization, idea extraction (abstraction) and algorithm thinking [12]. These processes enable individuals to solve complex problems by solving small problems according to specific functions. [13] and [14] explain that in CT skills, one can solve problems effectively by dividing it into smaller components. Pattern recognition involves the process of identifying and applying frequency to data or problems. The process of generalization uses identified equations to make predictions or solve more general problems [12]. However, the abstraction process is used to determine patterns, to generalize specific objects, and to identify similarities in a set of objects [4]. Algorithms, meanwhile, play an important role in solving computer science problems, especially repetitive problems. Algorithms can be regarded as strategic thinking or step-by-step processing that involves structuring directions for solving a problem, achieving a goal or carrying out a task [4].

In twenty-first century learning, problem solving skills are critically needed. CT skills can help students think analytically and critically [15]. Therefore, in order for students to master CT skills, these skills need to be taught and practiced early in school [9]. Many studies have been conducted on CT by many researchers, but there are still few studies on the benefits and challenges of CT. Therefore, this study aims to identify the advantages and challenges of acquiring CT skills. It is also hoped that this study will 
provide awareness for teachers and students about CT skills in future.

\section{USE OF ICT IN EDUCATION}

Computational thinking (CT) is a process or skill that is fundamental to the field of computer science, but can be applied to other fields such as mathematics, physics, chemistry, sociology and everyday life [9], [16]. Apart from that it is also important to note that teachers are also required to obtain the CT skills in order for them to use the skills effectively in their teaching and learning activities and to guide students to solve problems and express themselves well [17]. Teachers' knowledge of CT impacts the way it is integrated into teaching and learning in the classroom [18]. Through continuous professional development, teachers can apply more appropriate approaches and pedagogy to developing students' CT skills, based on their needs [19].

It is also proven that CT skills can be applied in all disciplines, including STEM education [20], [21]. [20] states that CT includes strategies for analysing problems and designing solutions to be used in all disciplines, especially STEM, for conceptual learning and problem-solving. A key approach to supporting STEM education is to incorporate CT elements into STEM topics.

Various courses are offered to gain a deeper understanding of science. Introduction to applied computer science, computer science, programming, biology, chemistry, algebra and engineering are among the identified courses for introducing CT elements. In addition, courses in genetics, language programming and computer science research have been selected to experiment with the application of CT. Various programmes are being implemented at school and university level to enable students to gain proficiency in CT skills [22].

\section{Methodology}

The writing of this literature review has focused on research that has been carried out in computational thinking (CT) in education. Various databases have been used to find information related to this topic, such as Google Scholar, Mendeley, Sci Direct and LearnTechLib. Some of the keywords used to find information include "computational thinking (CT): benefits and challenges in education". The literature selected is limited to studies in Malay and English because these languages can be understood by the researchers. The selected studies date from 2015 until today. Many studies were found; however, only 55 studies were selected, focusing on studies looking at the benefits and challenges of applying computational thinking in education. Based on the selected studies, the next step was to collect the main points based on the keywords, using NVivo. The findings from the coding in each article were compiled and formulated into this paper.

The following research questions will be addressed in this literature review:

1) What are the benefits of applying computational thinking in education?
2) What are the challenges of applying computational thinking in education?

The research questions were designed to determine the focus of writing, to stay on the right track, and to make the writing more relevant. The focus of the first question is on the benefits of applying computational thinking in education for students and teachers. For the second question, the focus is on the challenges that students and teachers face in implementing computational thinking in education.

TABLE I: SUMMARY OF THE STUDIES SELECTED

\begin{tabular}{|c|c|c|c|}
\hline $\begin{array}{l}\text { Experimental } \\
\text { design }\end{array}$ & Location & $\begin{array}{l}\text { Research } \\
\text { focus }\end{array}$ & Area \\
\hline $\begin{array}{l}\text { Qualitative (8) } \\
\text { Quantitative (13) } \\
\text { Quasi } \\
\text { experimental (4) } \\
\text { Concept paper } \\
(30)\end{array}$ & $\begin{array}{l}\text { USA (25) } \\
\text { UK (2) } \\
\text { Malaysia (6) } \\
\text { China (2) } \\
\text { Turkey (3) } \\
\text { New Zealand (2) } \\
\text { Canada (1) } \\
\text { Sweden (1) } \\
\text { Cyprus (1) } \\
\text { Brazil (2) } \\
\text { Indonesia (1) } \\
\text { Greece (1) } \\
\text { Spain (1) } \\
\text { Ireland (1) } \\
\text { Australia (2) } \\
\text { Italy (1) } \\
\text { Brazil (1) } \\
\text { Estonia (1) } \\
\text { Switzerland (1) }\end{array}$ & $\begin{array}{l}\text { Educators } \\
(21) \\
\text { Students } \\
(34)\end{array}$ & $\begin{array}{l}\text { Application of } \\
\text { computational } \\
\text { thinking in } \\
\text { education (52) } \\
\text { Computational } \\
\text { thinking and } \\
\text { STEM (2) } \\
\text { Computational } \\
\text { thinking and } \\
\text { mathematics (1) }\end{array}$ \\
\hline
\end{tabular}

\section{FINDINGS THE BENEFITS OF APPLYING CT IN EDUCATION}

CT has greatly benefited students in technological learning in the twenty-first century. In this study, we identify these benefits as increased critical and analytical thinking, cultivation of CT in STEM education (Science, Technology, Engineering, and Mathematics), improving pedagogy and curriculum towards CT, and fostering CT skills through game-based learning (GBL). The following sections describe these benefits in more detail.

\section{A. Increased Critical and Analytical Thinking among Students}

In twenty-first century learning, problem-solving skills and abilities are critically needed. CT skills can help students think analytically and critically [23]. This aspect of CT enables individuals to focus on structured solutions. At present, CT skills engage with computer science and programming skills to enable students to show their abilities [14]. Critical teaching and learning of CT skills by developing scaffolded activities will motivate both boys and girls [24]. According to [25] and [26], CT is important to support new and advanced technology in the world. The highest level of CT is the process of abstraction. The adaption process helps to establish patterns, generalise to specific objects, and identify the same important features of a set of objects [4]. Through abstraction, students identify and see clearly the main problem or situation, even though there are complex or irrelevant details. A study conducted by [2] found that integrating CT into teaching and learning increases students' analytical skills and achievements in CT areas, and 
tallies with academic achievement in general. Students can prepare themselves for the digital economy by learning CT and coding languages as a good foundation [27].

CT focuses on developing cognitive process in class [5]. Meanwhile, according to [28], human behaviour can influence and create strategies towards individual attitudes in learning. [29] also state that using CT skills intensifies the understanding needed to create connections with others around the individual in the world of technology. In addition, [30] suggest that previous learning experience related to the social, emotional, and cognitive development of students will reflect learning behaviour. Based on the above views, it can be stated that students are not only tool users but also tool builders. According to CT skills can build automated and productive solutions to solve problems by developing students' own ways of thinking [31] and [32]. The learning styles of the present generation achieved their goal through the integration of information and communication technology (ICT) [33].

\section{B. Cultivating Skills in STEM Education among Students}

A key approach to supporting STEM education is to cultivate CT elements in teaching and learning [21]. According to [34], developing problem solving and logical thinking skills in STEM activities helps students to learn CT skills. Computer science help students to explore CT skills that can then be used for problem solving in all disciplines [35]. The teaching of CT skills in computer science and STEM can support students to identify and solve problems in higher education as a whole [36]. [1] state that hands-on activities and experiences and prior knowledge help to create students' awareness to easily understand CT skills by effective problem-solving. For the purposes of hands-on learning for CT, mobile application development can be used In the research of [37], STEM is relevant in clarifying the meaning of CT and facilitating educational practice. [30] finds a correlative relationship between CT and the mathematics and science domains. It is clear that integrating STEM skills into CT learning has a positive impact on student achievement by driving new innovation skills.

\section{Improving Pedagogy and Curriculum Towards CT}

For teachers, the taxonomy aims to provide a clear set of concrete practices to guide classroom teaching and curriculum development. It helps teachers understand how they can use computational thinking practices in their classrooms and supports them in developing the quality of their lessons. This taxonomy serves as a way to improve existing pedagogy and curriculum with more advanced computational thinking practices in the twenty-first century [38]. Therefore, teachers should be prepared to follow these developments to achieve better educational goals, and research results show that science teachers have the essential level of knowledge [39]. This is because teachers are one of the key leaders responsible for the teaching and learning process [40]. In creating effective teachers, the faculty of education should be able to build and produce professional teachers in their respective fields, including science. Therefore, existing science teachers are expected to possess computational thinking skills: not only computational thinking skills through the use of technology such as computers, but also those involving cognitive processes in solving complex problems [41], [42].

[43] state that the unplugged method of CT could develop elementary teachers' understanding of how these ideas connect and fit into their classrooms. Another study by of [43] developed a CT toolkit (abstraction, decomposition, patterns, and debugging) for teachers to scaffold and use in elementary classrooms to expose students to CT skills. In addition, to attract teachers to adapting technology and computing, many schools include these skills in their curriculum for the early stages, so that teachers integrate computer science into other subjects [44]. In this regard, the new curriculum can address technology to develop CT education.

\section{Fostering CT Skills through Game-Based Learning (GBL)}

Game-based learning (GBL) to improve CT has been designed as a pedagogical framework for students in education [38]. Digital games have proven attractive and engaging for all groups of people, who are able to learn through gameplay. AgentSheets, designed by Alexander Repenning, improves algorithm design skills and creation of logical rules, and teaches the concept of automation [45]. Alice and Kodu are visual programming environments, which both focus on 3D programming [46], [47]. GBL like AgentSheets, Alice and Kodu focused on fostering basic programming concepts in an intuitive and playful way to improve CT skills.

Robot programming has also been regarded as a form of game-based learning [48]. In addition, Scratch is a successful application to teach programming to K-12 students and foster CT skills [10], [29]. [49]. TAPASPlay leverages an interaction style based on tangible objects and virtual reality (VR) by achieving the objective of fostering CT skills through GBL. VR expands the playfulness of the system and builds an attractive and collaborative learning environment. According to [31], modern students can develop their own way of thinking when they realize that computers can produce automated and effective solutions to problems. The integration of information and communication technologies is believed to fit the learning styles of the current generation [33].

The latest literature shows a growing interest in CT [35], and describes the importance of CT among students and teachers in education. According to [50], CT skills can be vastly are developed through collaborative and game-based learning like TAPASPlay, which provides a playful environment.

\section{Challenges of Using CT in Education}

While there are many benefits of computational thinking in education, there are also some challenges faced in implementing computational thinking in teaching and learning.

\section{A. Teachers' Understanding of CT}

One main challenge is teacher's understanding of the concept of computational thinking. Lack of understanding of 
this concept has led to a lot of problems faced by teachers, such as the infrastructure needing to be provided, time constraints to implement computational thinking skills in teaching and learning activities, lack of teaching materials and assessment strategies, and low levels of knowledge and computer use. This is linked to the fact that many teachers do not attend any training related to computational thinking [51]. The findings of a survey of 159 respondents indicate that $83.6 \%$ had never attended any training related to computational thinking, 54\% were uncertain of the concept of computational thinking, and $31.4 \%$ did not know about the concept of computational thinking.

In addition, this lack of knowledge related to the concept of CT has often led teachers to assume that computational thinking is a skill related to technology and is not applicable to other subjects. This statement is less in line with the studies conducted by [5] and [37], which show that computational thinking is not just about using computers, but is instead related to the cognitive process of solving a problem, and with CT skills, people can understand the problem they are facing and develop a reasonable solution. Low levels of knowledge will also have an impact on teachers' individual capabilities [52].

Furthermore, a lack of understanding of the concept of computational thinking is also faced by primary school teachers. The findings of the study conducted by [12] show that very few respondents were able to provide a complete definition of computational thinking. [53] also found that trainee teachers often misunderstand the concept of computational thinking, believing that it is a skill that involves technologies such as PowerPoint, Powtoon, video, or internet. Only a small number of trainee teachers could correctly articulate the concept of computational thinking skills as skills used in the thinking process to solve problems using logical, systematic, structured and creative thinking.

\section{B. Teachers' Lack of Confidence in Using CT}

There are also teachers who lack confidence in implementing computer skills in teaching and learning. Teachers lack confidence in the teaching of computational thinking because of their low pedagogical knowledge, and they need ongoing professional training to help them prepare for all aspects of teaching CT [19]. These problems are challenges that need to be overcome to ensure that students are able to master computational thinking skills.

High levels of confidence will impact teachers' teaching and learning as they will result in greater commitment and job satisfaction [54], [55]. Therefore, teachers need to have high confidence in implementing the concept of computational thinking, and teachers need to be provided with sufficient teaching resources to enhance students' learning outcomes. The provision of teachers who are capable of teaching computational thinking is generally the main challenge faced in integrating computational thinking into education [11], [56]. This is because most teachers are not given formal instruction and training to implement these skills in teaching and learning.

\section{Teachers' Lack Skills to Implement CT}

For teachers who are already teaching STEM subjects in school, they should have no problems when implementing computational thinking in teaching and learning. However, they may still not understand how these skills are used in the classroom [43]. According to [57], teachers who teach computer science find it difficult to integrate algorithmic thinking into teaching and learning processes. A study conducted by [58] found that attitudes toward science, mathematics and technological competencies influence the implementation of computational thinking.

Teachers should have strong pedagogical skills and be formally exposed to computational thinking. Most teachers do not yet recognize computational thinking as a fundamental concept in the new digital technology curriculum because they are less exposed to computational thinking in the early stages of their studies [19]. [35]. They need to be given special training in order to master the concepts and skills of computational thinking, regardless of their specialty and academic achievement before being placed in schools.

In addition, there are also teachers who are less skilled in using new technologies, because they are time-consuming and difficult to learn [7]. By implementing computational thinking, teachers not only need to learn how to use computers but also provide a learning environment for students to experience and learn about computational thinking [59]. This is one of the challenges that teachers face, as they not only need to know the content of the pedagogy but also how to integrate new technological skills and implement computational thinking in teaching and learning processes.

\section{Students' Acceptance towards CT}

Students' acceptance of computational thinking is also a challenge in education because many aspects need to be considered, such as thinking ability, education level, gender, and discipline [24]. With these skills, students can understand the difficulty level of a problem and learn how to solve it, while teachers can see how well the student solves the problem. If teachers are able to implement this concept in the teaching and learning process, students will be able to apply their knowledge to real situations [24]. However, if teachers are not able to implement CT in the teaching and learning process, students will not have the opportunity to learn this concept.

\section{DISCUSSION}

In order to ensure that teachers have a solid understanding of the concept of computational thinking, in addition to attending training and workshops, they need to be given strong skills from the beginning. The levels of teachers' understanding and skills are interrelated, because without understanding the concept of computational thinking, teachers will not be able to implement problem-solving skills in teaching and learning. It is important to provide professional development opportunities related to the curriculum needs of teachers in their respective fields.

These opportunities can show teachers how to integrate the concept of computational thinking into their existing teaching plans, or to develop and introduce any teaching pedagogy that will enable them to be confident in the environment of computational thinking skills. This challenge 
needs to be overcome because it will affect the learning level of the students. These computational skills can also help students solve problems in a variety of ways, and can be used in all subjects and in their lives. Fig. 2 summarizes the findings.

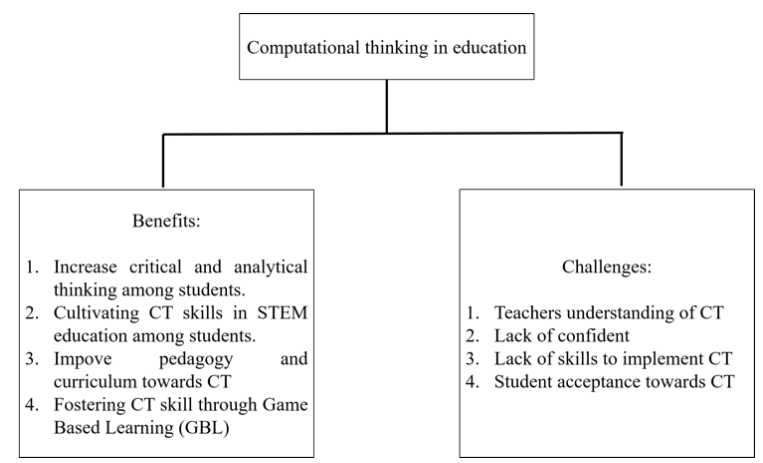

Fig. 1. Summary of the benefits and challenges of applying computational thinking in education.

\section{CONCLUSION}

In conclusion, based on the literature review of the 30 selected articles, there are many benefits of applying computational thinking in education. CT can not only increase critical and analytical thinking among students, but it can also cultivate CT skills among students in STEM education. The benefits of applying computational thinking also improve pedagogy and curriculum towards CT, and CT skills can be fostered through game-based learning. The application of computational thinking not only enables us to shape our field of education in a positive way, but also enables students to be more competitive and capable of solving various problems. Moreover, it has the potential to make educators more creative in educating the younger generation. However, there are many challenges in the implementation of computational thinking in the field of education, such as low levels of knowledge and skills in the implementation of computational thinking and lack of exposure to this concept. Research also shows that that students' acceptance towards CT is one of the challenges that our educators need to face in implementing CT. Although there are many challenges, these are not expected to be a barrier to implementing computational thinking in various fields of education, not only in STEM subjects, as various initiatives have been undertaken to enable the implementation of computational thinking in education, including ensuring that teachers have a high level of knowledge and readiness in relation to computational thinking.

\section{CONFLICT OF INTEREST}

The authors declare that there is no conflict of interest regarding the publication of this paper.

\section{AUTHOR CONTRIBUTIONS}

Noor Desiro, Rohanilah Nalini and Yogeswary analyzed the papers and wrote the draft of the article and Fariza supervised the research, review and improved the article; all authors had approved the final version.

\section{ACKNOWLEDGEMENT}

This study was conducted under GG-2019-068 research grant.

\section{REFERENCES}

[1] L. Shanmugam, S. F.Yassin, and F. Khalid, "Enhancing students' motivation to learn computational thinking through mobile development module (M-CT)," International Journal of Engineering and Advanced Technology (IJEAT), vol. 8, no. 5, pp. 1293-1303, 2019.

[2] J. Lockwood and A. Mooney, "Computational thinking in education: Where does it fit?" International Journal of Computer Science Education in Schools, vol. 2, no. 1, pp. 1-20, 2017.

[3] J. M. Wing, "Computational thinking," Communications of the ACM, vol. 49, no. 3, pp. 33-35, 2006.

[4] J. M. Wing, Computational Thinking: What and Why? TheLink - The Magaizne of the, 2010.

[5] C. C. Selby and J. Woollard. (2014). Refining an understanding of computational thinking. [Online]. Available: https://eprints.soton.ac.uk/372410/1/372410UnderstdCT.pdf

[6] K. Y. Chang, "A feasibility study on integrating computational thinking into school mathematics," School Mathematics, vol. 19, no. 3, pp. 553-570, 2017.

[7] M. Kist et al., "Computational thinking in K-12: An analysis with mathematics teacher," EURASIA Journal of Mathematics, Science and Technology Education, 2020, vol. 16, no. 6, pp. 1305-8223.

[8] A. Yadav, H. Hong, and C. Stephenson, "Computational thinking for all: Pedagogical approaches to embedding a 21 st century problem solving in K-12 classrooms," TechTrends, vol. 60, pp. 565-568, DOI: 10.1007/s11528-016-0087-7, 2016.

[9] L. Ribeiro et al., Computational Thinking: Posibilities and Challenges in Theoretical Computer Science, pp. 22-25, IEEE, 2013.

[10] S. Grover. (2013). OPINION: Learning to Code Isn't Enough. [Online]. Available:

https://www.edsurge.com/n/2013-05-28-opinion-learningto-code-isn-t -enough

[11] J. Voogt et al., "Computational thinking in compulsory education: Towards an agenda for research and practice," Education and Information Technologies, vol. 20, no. 4, pp. 715-728, 2015.

[12] I. Corradini, M. Lodi, and E. Nardelli, "Conceptions and misconceptions about computational thinking among Italian primary school teachers," in Proc. the 2017 ACM Conference on International Computing Education Research, Tacoma (WA), United States, 2017.

[13] A. Csizmadia et al. (2015). Computational thinking — A guide for teachers. [Online]. Available: https://www.semanticscholar.org/paper/Computational-thinking-a-gui de-for-teachers-Csizmadia-Curzon/b8741512fec1821197c2f54e0bfad bdfef2d5302

[14] E. Relkin, L. Ruiter, and M. U. Bers, “TechCheck: Development and validation of an unplugged assessment of computational thinking in early childhood education," J Sci Educ Technol., vol. 29, pp. 482-498, 2020.

[15] S. Einhorn, "Microworlds, computational thinking, and 21st century learning," LCSI White Paper, 2012.

[16] P. Sengupta et al., "Integrating computational thinking with K-12 science education using agent-based computation: A theoretical framework," Education and Information Technologies, vol. 18, no. 2, pp. 351-380, 2013.

[17] S. Kassan, K. F. Looi, and Y. M. Tham, Buku Teks Asas Sains Komputer, Kementerian Pendidikan Malaysia: Percetakan Rina, 2016.

[18] R. J. Whittle, A. Telford, and A. C. Benson, "The 'perfect' senior (VCE) Secondary physical education teacher: student perceptions of teacher-related factors that influence academic performance," Australian Journal of Teacher Education, vol. 40, no. 8, 2015.

[19] M. Bower et al., "Improving the computational thinking pedagogical capabilities of school teachers," Australian Journal of Teacher Education, vol. 42, no. 3, pp. 53-72, 2017.

[20] J. M. Wing, "Computational thinking and thinking about computing," Philosophical Transactions of the Royal Society of London A: Mathematical, Physical and Engineering Sciences, vol. 366, no. 1881, pp. 3717-3725, 2008.

[21] A. Estapa, A. Hutchison, and L. Nadolny, "Recommendations to support computational thinking in the elementary classroom," International Technology and Engineering Educators Association, vol. 77, no. 4, pp. 25-29, 2018.

[22] K. M. Yusoff, N. S. Ashaari, T. S. M. T. Wook, and N. M. Ali, "Analysis on the requirements of computational thinking skills to 
overcome the difficulties in learning programming," International Journal of Advanced Computer Science and Applications, vol. 11, no. 3, pp. 244-253, 2020.

[23] S. Gretter and A.Yadav, "Computational thinking and media \& information literacy: An integrated approach to teaching twenty-first century skills, association for educational communications \& technology,” Tech Trends, vol. 60, no. 5, pp. 510-516, 2016.

[24] C. Angeli and M. N. Giannakos, "Computational thinking education: Issues and challenges," Computers in Human Behavior, pp. 106-185, 2019.

[25] S. Hunt, Computational Thinking, 2012

[26] M. Mohaghegh and M. McCauley, "Computational thinking: The skill set of the $21^{\text {st }}$ century," Department of Computing, Unitec Institute of Technology, Auckland, New Zealand Faculty of Engineering, The University of Auckland, Auckland, New Zealand, 2016.

[27] L. S. Theam et al., "Pupils' responses to introduction to programming using computational thinking skills and brain-based teaching structure," Jurnal Penyelidikan Dedikasi Jilid 12, 2017.

[28] S. Ellis and J. Tod, Behaviour for Learning: Proactive Approaches to Behaviour Management, Routledge, Oxon, UK, 2013.

[29] K. Brennan and M. Resnick, "New frameworks for studying and assessing the development of computational thinking," presented at the Proceedings of the 2012 Annual Meeting of the American Educational Research Association, Vancouver, Canada, 2012.

[30] S. Powell and J. Tod, A Systematic Review of How Theories Explain Learning Behaviour in School Contexts, EPPI-Centre, Social Science Research Unit. Institute of Education, University of London, 2014.

[31] Ö. Korkmaz, R. Çakir, and M. Özden, "A validity and reliability study of the computational thinking scales (CTS)," Computers in Human Behavior, doi:10.1016/j.chb.2017.01.005, 2017.

[32] A. Jaokar. (2013). Evolving the definition of computational thinking. [Online]. Available: http://www.opengardensblog.futuretext.com/archives/2013/07/evolvin g-the-definition-of-computational-thinking.html

[33] K. Osman, L. C. Hiong, and R. Vebrianto, "21st century biology: An interdisciplinary approach of biology, technology, engineering and mathematics education," ProcediaSocial and Behavioral Sciences, vol. 102, pp.188-194, 2013.

[34] N. Romainor, C. A. Talib, and N. W. A. Hakim, "The necessity of computational thinking in STEM education: An analysis with recommended research," SEAMO Recsam, pp. 1-12, 2018.

[35] A. Yadav, S. Gretter, J. Good, and T. McLean, "Computational thinking in teacher education," Emerging Research, Practice, and Policy on Computational Thinking, Springer International Publishing, Cham, pp. 205-220, 2017.

[36] B. Czerkawski, "Computational thinking in virtual learning environments," in Proc. e-Learn: World Conference on e-Learning in Corporate, Government, Healthcare, and Higher Education, pp. 993-997, 2015.

[37] Y. Li et al., "Computational thinking is more about thinking than computing," Journal for STEM Education Research, vol. 3, pp. 1-18, 2020.

[38] D. Weintrop, N. R. Holbert, M. Horn, and U. Wilensky, "Computational thinking in constructionist video games," IJGBL, vol. 6, no. 1, pp. 1-17, 2016.

[39] T. Rahayu and K. Osman, "Knowledge level and self-confidence on the computational thinking skills among science teacher candidates," Jurnal Ilmiah Pendidikan Fisika Al-BiRuNi, vol. 08, no. 1, pp. 117-126, 2019.

[40] E. S. Koç, "An evaluation of the effectiveness of committees of teachers according to the teachers' views, Ankara province sample," Procedia-Social and Behavioral Sciences, vol. 174, pp. 3-9, 2015.

[41] S .Cooper, L. C. Pérez, and D. Rainey, "K--12 computational learning," Communications of the ACM, vol. 53, no. 11, pp. 27-29, 2010.

[42] W. Shi, M. Liu, and P. Hendler, "Computational features of the thinking and the thinking attributes of computing: On computational thinking," JSW, vol. 9, no. 10, pp. 2507-2513, 2014.

[43] A. Yadav, R. Larimore, K. Rich, and C. Schwarz, "Integrating computational thinking in elementary classrooms: Introducing a toolkit to support teachers," in Proc. Society for Information Technology \& Teacher Education International Conference 2019, Chesapeake, VA: AACE, 2019.

[44] M. Guenaga, I. Menchaca, P. Garaizar, and A. Equiliz, "Trastea.club, an initiative to develop computational thinking among young students," TEEM 2017: Proceedings of the 5th International Conference on Technological Ecosystems for Enhancing Multiculturality, pp. 1-6, 2017.
[45] I. T. Monteiro et al., "Signifying software engineering to computational thinking learners with agentsheets and polifacets," $J$ Vis Lang Comput., vol. 40, pp. 91-112, 2017.

[46] D. Wang, T. Wang, and Z. Liu, "A tangible programming tool for children to cultivate computational thinking," Sci World J., 2014, no. 3 , pp. 1-10.

[47] L. Werner, J. Denner, S. Campe, and D. C. Kawamoto, "The fairy performance assessment: measuring computational thinking in middle school," in Proc. the 43rd ACM Technical Symposium on Computer Science Education, ACM, New York, pp. 215-220, 2012.

[48] S. Atmatzidou and S. Demetriadis, "Advancing students' computational thinking skills through educational robotics," Robot Auton Syst., vol. 75(PB), pp. 661-670, 2016.

[49] I. Cetin, "Preservice teachers' introduction to computing: exploring utilization of scratch," J Educ Comput Res., vol. 54, no. 7, pp. 997-1021, 2016.

[50] T. Turchi, D. Fogli, and A. Malizia, "Fostering computational thinking through collaborative game-based learning," Multimedia Tools and Applications, vol. 7, no. 8, pp. 13649-13673, 2019.

[51] T. Ling, C. Saibin, J. Labadin, and N. A. Aziz, "Preliminary investigation: Teachers' perception on computational thinking concepts," Journal of Telecommunication, Electronic and Computer Engineering, vol. 9, no. 2-9, pp. 23-29, 2017.

[52] T. Rahayu and K. Osman, "Knowledge level and self-confidence on the computational thinking skills among science teacher candidates," Jurnal Ilmiah Pendidikan Fisika Al-BiRuNi, vol. 08, no. 1, pp. 117-126, 2019.

[53] A. Rosdi, A. Idrus, and S. M. Salleh, Kemahiran Pemikiran Komputasional Dalam Kalangan Guru Pelatih IPG, Jabatan Teknolologi Pengkomputeran, Jabatan Ilmu Pendidikan, Jabatan Matematik Institut Pendidikan Guru Malaysia, Kampus Teknik, Bandar Enstek, Negeri Sembilan, 2018.

[54] A. M. Gunning and F. M. Mensah, "Preservice elementary teachers' development of self-efficacy and confidence to teach science: A case study," Journal of Science Teacher Education, vol. 22, no. 2, pp. 171-185, 2011.

[55] Z. Chen and A. S. Yeung, "Self-efficacy in teaching Chinese as a foreign language in Australian schools," Australian Journal of Techer Education, vol. 40, no. 8, p. 24042, 2015.

[56] J. Liu, C. H. Lin, E. P. Hasson, and Z. D. Barnett, "Introducing computer science to K-12 through a summer computing workshop for teachers," in Proc. the 42nd ACM Technical Symposium on Computer Science Education, pp. 389-394, ACM , 2011.

[57] K. Mills, C. Angevine, and J. Weisgrau, "Resources for computational thinking: Co-designing with teachers," Digital Promise, Washington, D.C.San Mateo, CA. Poster Session 3 SIGCSE '20, March 11-14, 2020, Portland, OR, USA.

[58] D. A. Sirakaya, "Investigating computational thinking skills based on different variables and determining the predictor variables," Participatory Educational Research (PER), vol. 7, no. 2, pp. 102-114, August 2020, ISSN: 2148-6123.

[59] A. D. Thompson, D. L. Lindstom, and D. A. S. Crawford, "Computational thinking: What went wrong?" Journal of Digital Learning in Teacher Education, vol. 36, no. 1, pp. 4-5, 2020.

Copyright $\odot 2021$ by the authors. This is an open access article distributed under the Creative Commons Attribution License which permits unrestricted use, distribution, and reproduction in any medium, provided the original work is properly cited (CC BY 4.0$)$.

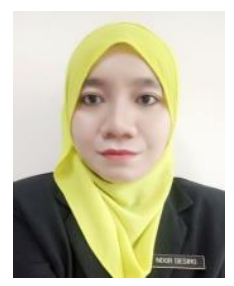

Noor Desiro Saidin got the Bachelor of education (information technology) with honours from Sultan Idris Education University in 2014. She served as a teacher at SMK Matunggong one of the secondary school in Kudat, Sabah and she currently is pursuing a master's degree in education (resources and information technology) at the National University of Malaysia.

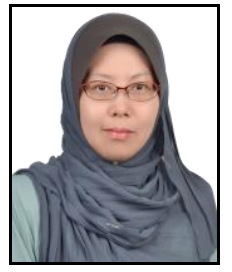

Fariza Khalid is a senior lecturer at the Faculty of Education, Universiti Kebangsaan Malaysia. Currently, she holds a position as a deputy director at the Center of Education Extension, whose role is to manage open distance learning programs for the university. Her specialization is in educational technology, and her research interests are: e-learning, augmented reality, emerging technologies for educational purposes and 


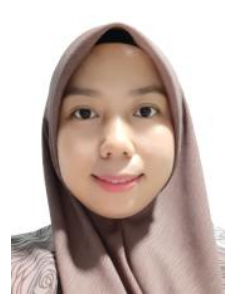

Rohanilah Martin got the bachelor of education (information technology) with honours from Sultan Idris Education University in 2014. She served as a teacher at La Salle Secondary School in Kota Kinabalu, Sabah and she is currently pursuing a master's degree in education (resources and information technology) at the National University of Malaysia.

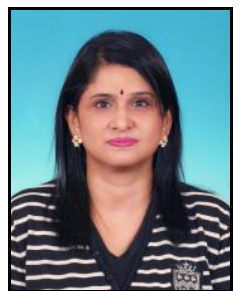

Yogeswary Kuppusamy got the bachelor of economics with honours from The National University of Malaysia in 1999 and completed the diploma education in 2005. She served as a teacher at Emerald Primary School in Shah Alam, Selangor and she is currently pursuing a master's degree in education (resources and information technology) at the National University of Malaysia.

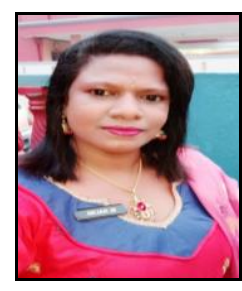

Nalini Munusamy completed the bachelor of business administration from University Utara Malaysia -KYM in 2001 and KPLI (diploma education) in 2005. She is a teacher by profession in the biggest cluster school, SJKT Simpang Lima, Klang, Selangor and she is pursuing her master's in education (resouces and information technology) at the National University of Malaysia. 